\title{
FICHTE AND THE UNIVERSALITY OF THE MORAL LAW
}

\author{
Claude Piché, Montréal
}

This is a working copy ("preprint"). It may differ from the published version and should not be quoted nor referenced. The final version was published in Philosophy Today, 52, no. 3-4, 2008, p. 228-235.

La version FRANÇAISE de ce texe intitulée « Loi restrictive et loi productive dans l'éthique fichtéenne " peut être trouvée ici sur Papyrus.

\begin{abstract}
In his lectures of 1806 on The Way Towards the Blessed Life, Fichte draws a distinction between lower and higher morality. According to him, the paradigm of the lower morality is to be found in Kant's ethics insofar as it promotes the uniformity of human conduct on the basis of a universal law. Even though Fichte recognizes that his own System of Ethics of 1798 contained some elements of this lower ethics, it is possible to show that the specific role each individual has to play in the moral world was already introduced in this work, which therefore anticipates the theme of the higher morality.
\end{abstract}

KEYWORDS: Fichte, Kant, moral law, lower/higher morality, uniformity

"We ought all to act in the same manner." This bold assertion is to be found in the fifth Part of $\S 18$ of the System of Ethics. With this sentence, Fichte raises the question of the realisation of the moral law by a plurality of rational beings. He is entitled to raise this question at that particular point of his discussion, because, earlier in the same paragraph, he had deduced what has come to be known as "interpersonality". As we know, in order for an individual to recognize herself as a free being, she must necessarily posit the existence of another free rational being. From that point on, the realisation of morality becomes a collective task. All rational beings pursue the same end; that is, the absolute independence and self-sufficiency of reason, and in order to attain this common goal, they should all act in the same way. Fichte stresses this aspect of the collective realisation of morality by saying that we should strive toward "uniformity

\footnotetext{
${ }^{1} S S, G A \mathrm{I} / 5,211$.
} 
of acting" (Gleichförmigkeit des Handelns ${ }^{2}$ ). The question is then: How are we to understand Fichte's requirement of uniformity of moral conduct? Since the result of the deduction of intersubjectivity is that the I has to be particularized, that it has to discover itself as an empirical $\mathrm{I}$, the question then arises as to how such an individual $\mathrm{I}$ is to relate to the pure rational law and to its universal character.

In what follows, I intend to examine this question in light of the criticisms that Fichte addresses to the Kantian conception of morality, and, in particular, in light of the conception of universality underlying Kant's moral law. In the section where Fichte writes that we should all act in the same manner, he formulates two remarks concerning the way Kant exposes his categorical imperative, two remarks that will retain our attention. As Fichte expressly makes these remarks from his own "point of view," they will help us to circumscribe his position on the universality of the moral law. But even though he does not agree with Kant on the exact role of universality in the moral law, Fichte, in 1798, nevertheless accepts the Kantian idea of a unanimous agreement among rational beings, a position that he will later have to qualify.

The second part of this paper will focus on Fichte's lectures of 1806, The Way Towards the Blessed Life, in which he introduces the famous distinction between "lower" and "higher" morality, a distinction that will allow us to determine Fichte's final stand on the "uniformity of acting," the theme he developed in 1798. Once again, Kant will serve here as a guiding thread insofar as he becomes considered, from then on, to be a proponent of the lower level of morality, a morality that aims at nothing other than a uniforming of human conduct. In my final remarks, I shall come back to the System of Ethics of 1798 in order to see in what sense the accusations brought against Kant's ethics in 1806 might also be directed against Fichte's own System of

\footnotetext{
${ }^{2} S S, G A \mathrm{I} / 5,213$.

${ }^{3} S S, G A \mathrm{I} / 5,211$.
} 
Ethics, as he himself admits. But I shall also try to show that some aspects of the higher morality, namely the uniqueness of the role each person has to play as well as the creative character of the law, were already somewhat anticipated in 1798 , and that despite the evolution that the principles of the Wissenschaftslehre went through, the concrete content of Fichte's ethics did not undergo a radical change.

Let us start by reading the passage of the System of Ethics in which the sentence stating the necessary uniformity of the actions of all moral subjects is introduced. As has already been said, Fichte comes here to the point where morality can be envisaged as a collective task, as the task of all rational beings: "As we have seen, the moral final end of every rational being is the self-sufficiency of reason as such, and hence the morality of all rational beings. We ought all to act in the same manner." ${ }^{4}$ Morality is a task that concerns everyone; hence all rational beings must agree on this common end, on what has to be done. This is precisely where Kant comes into Fichte's argumentation. In fact, because Kant does not feel the need to deduce the existence of a plurality of rational beings or, in other words, because he takes the existence of others for granted, ${ }^{5}$ he can allow himself to refer to them, albeit only implicitly, in the general formulation of his categorical imperative. And this is the case when Kant draws attention to the universality required of the maxim that the moral subject intends to adopt: it must take the form of a universal law. The concept of universality is understood in two senses here: the necessary applicability of the law to every case, without exception, as well as the validity of this law for everyone in virtue of its rational character: the acceptability of the maxim of action is what must potentially be

\footnotetext{
${ }^{4} S S, G A \mathrm{I} / 5,211$, trans. D. Breazeale and G. Zöller.

${ }^{5}$ SS, GA I/5, 201; see also WLnm[K], GA IV/2, 141-142.
} 
agreed to by everyone. ${ }^{6}$ Fichte gives the following formulation of the Kantian categorical imperative, a formulation that is very close to the one found in the Critique of Practical Reason: "Act in such a way that you could think of the maxim of your will as a principle of a universal legislation." ${ }^{, 7}$ Immediately after this formulation, Fichte introduces two remarks by which he aims to insist on the limited scope of this formulation. The first remark stresses the fact that the agreement Kant is alluding to is "only" an "ideal" one. Kant is in no way aiming here at real universal assent. The second remark, on the other hand, points out that the assent of other rational beings, implicitly invoked in Kant's formula of the categorical imperative, plays "only" a "heuristic" role, which, for this reason, does not justify us in considering this formulation of the moral law to be "constitutive". Let us examine these two remarks more closely, beginning with the second one.

By claiming that Kant's categorical imperative does not present us with a "constitutive" but rather with a "heuristic" principle, Fichte brings to the fore what could be called the derivative character of this imperative. In his eyes - and Kant would certainly not disagree with him - this formulation of the moral law is not the original moral principle. Firstly, it is presented here as an imperative, and this means that it expresses an "ought", which is precisely the form that the general moral law has to adopt when it is addressed to finite rational beings; in other words, it expresses an obligation. Secondly, the Kantian formulation of the categorical imperative does not directly enjoin the finite moral subject to act in view of attaining the selfsufficiency of reason, but rather to examine the validity of her maxim in light of a possible universal legislation and agreement, after she has made her choice. As Fichte explains, the procedure implicated by this imperative can be introduced only after the moral subject has

\footnotetext{
${ }^{6}$ For these two components of the concept of universality, see Kant, Kritik der Urteilskraft, § 59, $A K \mathrm{~V}, 354$.

${ }^{7} S S, G A \mathrm{I} / 5,211$.
} 
already chosen a maxim. The procedure as such does not have anything to do with the act of choosing itself; it is simply a heuristic device designed to verify, retroactively, if the moral agent had been mistaken in her choice. In principle, however, the pure moment of rationality occurs as the choice is being made. And it is this dimension of rationality that is central to the moral experience, according to Fichte. In light of this, the Kantian procedure appears as a mere "consequence" (Folgerung ${ }^{8}$ ) of the rationality of the original act of choosing. In $\S 18$ we find the following expression used to characterize a moral conviction: Fichte speaks of propositions that are "really in conformity with reason, and therefore universally valid." 9 The word "therefore" (sonach) points to precisely what Fichte has in mind when he argues that the Kantian categorical imperative states a mere corollary of the moral law as he conceives it: indeed, a maxim is not morally good because it receives the assent of every rational being; rather, the maxim is universally valid because it is intrinsically rational. The rationality of the acting subject is expressed by what Fichte considers to be the true formulation of the moral law: The will has as its ultimate goal the "absolute self-sufficiency of reason."10 This autonomy and autarky of reason is absolute, in that it depends on no external condition at all. The duty to attain this goal is hence the genuine content of the categorical imperative.

On the other hand, by stressing the merely "ideal" character of the procedure just mentioned, Fichte wants to show that the moral subject, when it comes time to assess the moral value of her maxim, does not in fact leave the sphere of her own inner reflection. The procedure we are invited to perform is rather a sort of thought-experiment, within the confines of the individual. It consists in asking oneself how the other rational subjects would react to the maxim guiding the action. This is fine as long as we are considering the heuristic function of the

${ }^{8} S S, G A \mathrm{I} / 5,212$.

${ }^{9} S S, G A \mathrm{I} / 5,222$.

${ }^{10} S S, G A \mathrm{I} / 5,212$. 
principle described above, but the other - rather critical - remark of Fichte's concerns the necessity to come to a real and concrete agreement among human beings. Then, the search for a complete factual agreement is not primarily undertaken in order to find a sure criterion for moral action, but in order to concretely realize morality in the world. To be sure, Kant raises an important issue when he refers to the unanimous assent of all rational beings in matters of morals; on Fichte's view, this procedure does not involve the moral subject in a satisfactory manner, since the universal agreement remains at a virtual level. This means that the Kantian subject does not feel the additional need, besides checking the rightfulness of her moral conviction when she is about to act, to try to convince everyone else that her conviction is the right one and that it should be adopted by all. According to Fichte, if the ultimate goal of the acting subject is to seek the realization of the morality of all, it is a duty to try to persuade everyone of the rightfulness of one's conviction, especially when one is intimately convinced of its validity. The sharing of one's convictions takes place in society through a process of mutual influence among individuals. In $\S$ 18, Fichte mentions three institutions in which such exchanges take place and in which different levels of agreement can be reached: the church, the State, and what he calls the "learned public," by which he means, among other things, the universities and other institutions of higher learning. ${ }^{11}$ It will not be necessary here to describe these institutions in detail. This just serves to remind us how serious Fichte is when, beyond Kant's virtual consultation of the totality of rational beings, he specifically mentions the institutions through which each finite rational being has to concretely fulfill her duty of realizing unanimity.

But the question remains: What does Fichte mean when he writes "we ought all to act in the same manner"? How far does this uniformity of behaviour have to go? One aspect, abundantly stressed in $\S 18$, is that of the agreement about moral convictions. For instance, we

${ }^{11} S S, G A \mathrm{I} / 5,213-227$. 
read at the end of the paragraph sentences like these: "men should agree among themselves" and "all [the educated as well as the uneducated public] have the same convictions, and the conviction of one is the conviction of all ${ }^{12}$. In light of what we have discussed, this answer to the question was foreseeable; an agreement concerning principles is certainly what Fichte has in mind. But is this answer complete? Is it an overstatement when Fichte ultimately speaks not only of unanimity of convictions but of "uniformity of acting"? In light of $\S 18$, one thing is certain: Fichte does not mean here that the concrete course of action should be exactly the same for everyone, so that all human behaviour would end up in total uniformity. This cannot be the case, for the simple reason that Fichte retains Kant's way of arguing in such matters. He says repeatedly that every person should agree with my conviction and act according to it were she to find herself "in the same situation". ${ }^{13}$ Now, in human life, as we know, situations vary widely, so that complete uniformity of conduct among individuals does not have to be feared. Moral subjects are therefore not likely to act like clones of each other. Notwithstanding the fact that maxims do not play a role in Fichte, as they do in Kant, we can conclude that both thinkers have similar views on the nature of the universal agreement (be it ideal or real): the consensus remains at the level of the principles, of what is rational. ${ }^{14}$ But we shall see that this unanimous

\footnotetext{
${ }^{12} S S, G A \mathrm{I} / 5,226$.

${ }^{13} S S, G A$ I/5, 211, 212. See also Günter Zöller, "Die Individualität des Ich in Fichtes zweiter Jenaer Wissenschaftslehre (1796-99),“ Revue internationale de philosophie, 206, 1998, p. 650. ${ }^{14} S S, G A \mathrm{I} / 5,221,226$. If we pay attention to the fact that the expression "uniformity of acting" is introduced in the subsection of $\S 18$ in which Fichte develops the concept of the state, we may draw a parallel with the Sittenlehre of 1812, where two points of unification are distinguished from each other: the state and the church, the first dealing with "agreement over action" (Überseinstimmung über das Handeln), while the second is devoted to the "agreement over insight" (Überseinstimmung über die Einsicht), the latter being likely to correspond to the "agreement over convictions" of 1798. Interestingly enough, according to the Sittenlehre of 1812 , the agreement over action is expressed in the Sitte, which has been historically codified in the form of negative "laws" ("not to steal, not to kill" etc). In complying with those prohibitive laws, human beings all "act" in the same way, albeit only negatively. This is one way of interpreting the meaning of the "uniformity of acting" alluded to in the System of Ethics, although
} 
agreement concerning rational convictions will appear to the later Fichte to be insufficient.

Unanimity in moral convictions is only a part, and perhaps not even the most important one, of moral life. In other words, for the Fichte who has left Jena for Berlin, this universal consensus belongs to a preliminary stage of moral existence, and hence does not represent its fulfillment.

We now come to the later Fichte and to the difference he introduces between lower and higher morality. It goes without saying that, from a purely theoretical point of view, the exact counterpart of the System of Ethics of 1798 is to be found in Fichte's lectures on ethics of 1812. It is worth noting, however, that Fichte, in these lectures, does not have recourse to the distinction between higher and lower morality. ${ }^{15}$ Rather he seems preoccupied with giving a unified picture of his ethics, without trying to confine Kant, as he does in his text of 1806 on the Blessed Life, to the lower level of morality. In fact, even though, in 1812, Fichte directs a few critical remarks at the Kantian conception of morality, his appraisal of Kant's moral philosophy is laudatory overall. This leads us to believe that in his popular writing On the Way to the Blessed Life, Fichte is seemingly less interested in a precise and nuanced presentation of his moral philosophy than in a vivid and simplified exposition of the two points of view from which ethics can be envisaged. With this in mind, we can nonetheless use the distinction between lower and higher morality drawn in 1806 to assess the developments of the Sittenlehre of 1798 that we have examined with regard to the articulation of individuality and uniformity of acting. In other words, the recourse to the dichotomy between the two levels of morality might be allowed - and can indeed be highly revealing - as long as we bear in mind that it was designed to be accessible to a broader public

neither the version published in 1798 nor the lecture-course given on the same topic in 1796 contain any direct indications to this effect. See Sittenlehre 1812, GA II/13, 381; Vorlesung über die Moral SS 1796, GA IV/1, 118-123.

${ }^{15}$ It must be noted that in order to characterize Kant, in 1806 , as a proponent of the lower morality, Fichte explicitly restricts himself to the part of Kant's work previous to the Kritik der praktischen Vernunft. See Fichte, Die Anweisung zum seligen Leben, oder auch über die Religion (hereafter Anweisung), GA I/9, 108. 
and that it therefore has the status of, to use a Weberian expression, a distinction between two "ideal types" rather than of an accurate philosophical account of Fichte's ethics.

At the center of Fichte's conception of the lower morality is a law with the following characteristics: it is at once an "ordering" and an "equalising" law. ${ }^{16}$ The first instance he gives of it is the juridical law, which manifestly fulfills these two requirements. Firstly, the juridical law establishes a certain order among the citizens as it determines and guarantees everyone's sphere of freedom of action. Secondly, this law is a harmonizing and equalizing factor, in that all citizens enjoy the same rights and in that they are all alike, that is, all equal before the law. So far, Fichte's account is not particularly problematic. But his discussion becomes highly interesting when he introduces the moral law as another instantiation: he sees the moral law of the Kantian type as also being part of the lower form of morality. ${ }^{17}$ In fact, Kant's categorical imperative becomes paradigmatic of the entirety of the lower morality. And the reasons for this are quite obvious. When we consider the way Kant conceives his moral law, we discover that it also bears the two features that apply to the juridical law. ${ }^{18}$ Indeed, the moral law, like the juridical, establishes 1- an order and performs 2- an equalising function.

1- The moral law brings peace and serenity into the inner life of the moral subject by rejecting the inclinations as a determining factor of conduct. The Kantian conception of morality leads to a victory over the conflicting motivations of sensibility and self-love and thereby brings stability and balance (Gleichgewicht) to moral life. In order to achieve this, the moral law

\footnotetext{
${ }^{16}$ Anweisung, GA I/9, 107.

17 Anweisung, GA I/9, 108.

${ }^{18}$ At about the same time as Fichte held his lectures on the Anweisung, Schleiermacher was voicing a similar critique of the categorical imperative, arguing that the command (Gebot) contained in it gives it a "juridical" character. See his Brouillon zur Ethik (1805/06), Hamburg, Meiner, 1981, p. 47, see also p. 4.
} 
acquires, as Fichte says, a "negative" aspect. ${ }^{19}$ It has a restrictive character in that it prohibits wrongful actions more than it prescribes good ones, and in this it resembles the juridical law. The main purpose of this ethics is to urge each moral subject to not "do anything unlawful to others and to refrain from doing anything contrary to duty, no matter if it is or not forbidden by an explicit law of the state". ${ }^{20}$ This restrictive aspect of the moral law can best be seen when one considers the examples used by Kant in his Groundwork of the Metaphysics of Morals. We know that the first formula of the categorical imperative can be used to verify the soundness of a moral maxim. Now all four maxims that Kant introduces as examples in order to illustrate the procedure to follow in this test lead to negative results. The themes of the four thoughtexperiments are, namely, the following: is it moral to commit suicide, to make a false promise, not to develop one's own talents, and to refuse to provide help to someone in need? $?^{21}$ So, when Fichte claims that the moral law in its Kantian version is mostly negative, he no doubt has in mind this restrictive and prohibitive character of the categorical imperative, which serves primarily to discard morally unacceptable maxims.

2- The other aspect of the law of the lower morality that is present in the moral law as well in the juridical law is uniformity. If all acting subjects reject the external determinations of their wills, if they refuse the heteronomy entailed by sensible desires and inclinations, then they all agree to be subjected to one and the same rational law, and to act solely for the sake of duty. As we have seen, the rational core of this law is the complete independence and autarky of the will in the face of foreign determinations. This means that there is an ideal of self-sufficiency behind the categorical imperative and, precisely in this, all moral subjects complying with the

${ }^{19}$ Anweisung, GA I/9, 109, see also 137, 139, 140.

${ }^{20}$ Anweisung, GA I/9, 107-108, see also Über das Wesen des Gelehrten (1805), GA I/8, 77.

${ }^{21}$ Kant, Grundlegung zur Metaphysik der Sitten, AK IV, 421-423. 
command are alike: they are all similar in their rejection of heteronomy, and as rational beings they ideally all coincide.

If we leave Kant aside and turn now to Fichte's own attitude toward this theory of lower morality, two questions arise. Firstly, does what we have just seen imply that Fichte would be willing, after all, to soften or even revoke the distinction between juridical and moral law that he had painstakingly established in his Foundations of Natural Right? This is clearly not the case. The distinction certainly remains in force but the point worthy of interest with regard to the assignment of both the juridical and the Kantian moral law to the lower morality is that the categorical imperative shares with the juridical law its negative and restrictive aspect, which means that Fichte can no longer remain satisfied with this lower level alone; it has to be considered as, at most, a preliminary stage of moral life. ${ }^{22}$ The second question addressed to Fichte is the following: if, in 1798, he strongly insisted on the purely rational dimension of the moral law, that is, the complete self-sufficiency of the will, how are we now to interpret the allusion, in 1806, to the "formal self-sufficiency" and the" formal conformity to the law,"23 which, from then on, appear to be secondary elements from the standpoint of the higher morality? Moreover, if the moral law is a factor of uniformity among rational beings, what should we think of his insistence in 1798 - beyond Kant's own intentions - that all human beings should effectively share the same moral convictions? In fact, in his System of Ethics, by asking that a unanimous consensus on the convictions be concretely realized, Fichte did a great deal to promote the equalising function of the moral law. Yet, he is clearly conscious of these questions in 1806 and he goes so far as to admit that he devoted a lot of effort, during his years in Jena, to the two strands of the lower ethics, namely in his Foundation of Natural Right of 1796-97 and his

\footnotetext{
${ }^{22}$ Anweisung, GA I/9, 138.

${ }^{23}$ Anweisung, GA I/9, 149, 154.
} 
System of Ethics of $1798 .^{24}$ He does not disavow what he has done, but he now considers these matters from another point of view, namely that of the higher morality. He argues, for instance, that he had in no way claimed in his Sittenlehre of 1798 to have then reached the highest level of morality. This is to say that, in his eyes, his texts of the Jena period are still valid, as long as they are considered as an initial phase, within a wider conception of morality. They therefore appear insufficient only from the perspective of this wider conception. ${ }^{25}$

In order to understand the point of view that enables Fichte to relativize the status of the lower morality and its formalism, let us bring out a contrast by briefly sketching the central thesis of the higher morality or of what Fichte also calls the "true" or "authentic" morality. Like the lower morality, this higher level is centered on a law, one which, in this case, is not endowed with a merely restrictive function, but is, rather, a "productive law" (erschaffendes Gesetz $\left.{ }^{26}\right)$. It has a positive content in that it urges the moral subject to actively transform the sensible world by giving it a concrete moral form. Because of the very nature of this law, however, it is not easy to establish its exact content. In fact, the German word erschaffend might best be translated by the adjective "creative," and, because of this, the law in question cannot be stated in general terms: the "man of higher morality" has an immediate awareness of it. For instance, to designate the specific kind of virtue required at this higher level, Fichte speaks of "geniality" and of the virtuous person as a "genius." ${ }^{, 27}$ Now, if we recall the definition of genius Kant gives in the third Critique, we have to admit that the genius acts according to a rule, but that this rule remains

\footnotetext{
${ }^{24}$ Anweisung, GA I/9, 107-108.

${ }^{25}$ Anweisung, GA I/9, 107.

${ }^{26}$ Anweisung, GA I/9, 109, 154, see also Sittenlehre 1812, GA II/13, 334. Reinhard Lauth has shown that Fichte's insistence on the "creative" (erschaffend, schöpferisch) aspect of morality betrays the influence of Jacobi. See his "Elementare Pflicht und höhere Moral", in the same Vernünftige Durchdringung der Wirklichkeit. Fichte und sein Umkreis, Neuried, ars una, 1994, p. 410.

${ }^{27}$ Anweisung, GA I/9, 157, 161.
} 
unconscious to her. ${ }^{28}$ And Fichte seems to justify the indeterminateness of his conception on the basis of this fact. This explains why he nevertheless describes the higher level of morality in terms of a law, even though this law, as opposed to that of the lower morality, cannot be stated discursively. Moreover, not just anyone can elevate herself to the higher level of morality; the genius, for instance, is clearly a privileged person. The same goes for the natural "talents" according to Fichte: they belong to specially gifted persons, who do not have to wait for the command of a "categorical imperative" to give them free reign. ${ }^{29}$ It goes without saying that in The Way Towards the Blessed Life, a text dealing mainly with religion, these gifts have to be understood against the background of divinity, a topic that we can leave aside here.

There is one feature of the higher morality, however, that is particularly relevant to the assessment that Fichte makes of his earlier System of Ethics : the status of individuality. The argument for the lower morality goes as follows: while all individuals at this level look alike because the pure moral law is what defines their reality, it is nonetheless the case that each moral subject sees herself as a fully independent and self-sufficient will, as a will which holds sensibility in check and depends on nothing outside of reason. This is what Fichte calls the "belief" in the "formal self-sufficiency" (formale Selbstständigkeit) of the individual I. But this autonomy corresponds - and here Fichte has in mind the heroic ideal of the Stoic - to a form of self-assertion or of self-affirmation that must, according to him, be given up at the higher level. In other words, in order to gain access to higher morality, the moral individual has to give herself up, that is, to "annihilate" herself as an autonomous will. ${ }^{30}$ This might sound strange from the viewpoint of the classical Kantian conception of morality, but, for the later Fichte, it is an act of

\footnotetext{
${ }^{28}$ Kant, Kritik der Urteilskraft, $\S 46, A K \mathrm{~V}, 307-308$.

${ }^{29}$ Anweisung, GA I/9, 157-158.

${ }^{30}$ Anweisung, GA I/9, 149.
} 
the "highest freedom"31 to abandon one's freedom - conceived in terms of autonomy - and to put oneself in the service of the manifestation of the supersensible being ${ }^{32}$. But by accepting to give up her formal identity, the person henceforth accedes to a higher realm, where she discovers herself as part of a global plan, of which she accepts to become an "instrument", a "tool", but in the context of which, at the same time, she is endowed with a specific and unique role. The paradox in this transition from lower to higher morality is that, while giving up her independence as a pure self-asserting will; that is, by renouncing her individuality, the moral person sees herself assigned a unique moral task that cannot be shared by any other subject and that properly belongs to her. ${ }^{33}$ In the final analysis, while authentic morality requires the sacrifice of individuality, this morality does not establish uniformity of action within mankind, but rather an array of highly differentiated tasks for the sake of the totality.

To sum up, we might say that after Fichte's departure for Berlin, his moral theory underwent a certain evolution, but it would doubtless be unfair to claim that this change amounted to a radical break. At least, this is not how Fichte himself sees his own development in The Way Towards the Blessed Life: the higher morality outlined in these lectures does indeed complete his earlier conception, which drew heavily upon the Kantian approach. The latter now appears to him as a preliminary stage, as a minimal requirement, and for this very reason it remains indispensable. ${ }^{34}$ But, at the same time, this lower morality cannot be regarded as the final word concerning moral life: it is just one part of the story. Hence, we were led to realise that Kant's categorical imperative, together with the refinements Fichte brought to it in the

\footnotetext{
${ }^{31}$ Anweisung, GA I/9, 154.

${ }^{32}$ Anweisung, GA I/9, 160.

33 Anweisung, GA I/9, 160, see also 150, 154.

${ }^{34}$ See Marco Ivaldo, ,„»Das Wort wird Fleisch«. Sittliche Inkarnation in Fichtes Später Sittenlehre“, in H. G. von Manz and G. Zöller (eds), Fichtes praktische Philosophie. Eine Systematische Einführung, Hildesheim, Olms, 2006, p. 176, 198.
} 
System of Ethics, has a secondary status in comparison with the productive law put forward in 1806. We have seen that this creative law takes a different aspect for each moral subject who can raise herself to it, and that something like a "uniformity of acting" is, given this, all the more out of place.

Before closing this discussion, it might be relevant to come back to the System of Ethics in order to see if the criticism addressed to this work in The Way Toward the Blessed Life touches it in its entirety. In fact, the two aspects already mentioned, namely the uniformity of convictions and the self-assertion of the will, represent at most a step in Fichte's argumentation of 1798. Indeed, as soon as we reach the third part of the book at $\S 19$, devoted to "The Doctrine of Duties Proper," it becomes clear that Fichte's proposition "we ought all to act in the same manner" can nowise be interpreted in a strict sense. With the help of two examples taken, respectively, from $\S$ 19 and from $\S 32$, it can be shown that some of the elements present in the 1806 text, namely the self-annihilation of the individual as an autonomous will and the creative dimension of moral action, were already taken into account in the System of Ethics. In $\S 19$, for instance, Fichte quotes once again a Kantian proposition that expresses, this time, the content of the second formula of the categorical imperative in the Groundwork: "every human being is himself an end." As we know, the meaning of this formula is that we ought never to treat human beings merely as means, but at the same time as ends in themselves. Now on Fichte's view, this is certainly true of the way we have to consider other human beings, but in the case of a human being in the first person, this imperative takes a different twist: I have to admit that my end as a moral being is to be a "means" (Mittel), so that I have to regard myself as an "instrument" or a "tool" of the moral law. ${ }^{35}$ While in 1806 the moral subject has to regard herself as part of the manifestation of the supersensible, here, in 1798, we notice a similar attitude, in that the moral subject sees herself as

${ }^{35}$ SS, GA I/5, 230, see also Sittenlehre 1812, GA II/13, 372. 
part of the "presentation" (Darstellung) of reason in general. And as it is the case in 1806, this leads the individual acting subject to "forget" herself, to "vanish," in the sense that in fulfilling her duty the person "annihilates" herself as an individual for the sake of the realization of morality. No more than on the 1806 view is this process imposed upon the moral person from the outside. It is depicted here as an ultimate act of "free choice and of self-determination" on the part of the I. In so doing, the I agrees to take part in the "plan of reason" in which it is called to play a specific role. ${ }^{36}$ As we can see, not only the vocabulary used in this text, but also the final aim of the moral subject, namely self-forgetfulness in the name of the realization of a global plan, show striking resemblances with what has been seen in the text of 1806.

$\S 32$, moreover, entitled "Duties of the state official," also contains features that are relevant to our topic. Firstly, it reminds us that the description of moral duties in Fichte's System of Ethics is not limited to the general duties - concerning every human being - but also includes an exposition of the particular duties, thereby stressing the fact that the fulfilment of certain tasks in society must be entrusted to specific groups of persons. In the case at hand, being a state official means occupying one of the numerous social positions or estates (Stände), among which every human being has the duty to choose in order to channel her action and to realize, in a specific (and therefore efficient) manner, the goal of moral reason. This emphasis instantiates Fichte's concern with the necessary specification of moral action. The other element contained in $\S 32$, although it does not express the creative aspects of higher morality as explicitly as the text of 1806, nevertheless anticipates, in a certain way, the margin left open to the moral subject to initiate a course of action that cannot as such be specified in advance. The state official, whose duties are exposed in $\S 32$, corresponds, for Fichte, to the political leader who is entitled to enact legislation. In fact, we can discern in Fichte's elaboration of this example what will later become ${ }^{36} S S, G A \mathrm{I} / 5,231,244$. 
the two levels of morality. First, the legislator has the strict duty always to act according to the existing constitution. The civil order guaranteed by the juridical law is absolutely indispensable, as we have learned from Fichte's presentation of the lower morality. But the legislator also has the duty, as an educated and enlightened person, to do everything in her power to improve the existing constitution in order to gradually bring it closer to the unwritten model of the pure rational state. The form of those changes is not prescribed in advance, however, so that the legislator, in this case, must rely on her intellectual resources and on her own creative capacities. To be sure, Fichte does not express this second aspect, typical of the higher morality, in precisely these terms, but he points to the model of the rational political constitution as an "ideal" that the state official must constantly strive to reach. ${ }^{37}$ On a close reading of the System of Ethics, therefore, the subsequent developments of Fichte's moral philosophy do not come as a complete surprise.

${ }^{37}$ SS, GA I/5, 311, see also Anweisung, GA I/9, 109, 156. 